\title{
The Influence of Risk Management to the Return on Asset (ROA) Banking Sector (Case Study of Bank in Indonesia Listed in Indonesia Stock Exchange)
}

\author{
Eddy Winarso ${ }^{1, *}$, Imhmed Abdulgader Salim² \\ ${ }^{1}$ Faculty of Economic, Widyatama University, Indonesia \\ ${ }^{2}$ Faculty of Economic and Accounting, Sebha University, Murzuq, Libya
}

Copyright $\bigcirc 2017$ by authors, all rights reserved. Authors agree that this article remains permanently open access under the terms of the Creative Commons Attribution License 4.0 International License

\begin{abstract}
As companies in general, commercial banks in the operational as well have a goal to be able to get the maximum profit. Therefore, banks must maintain its financial ratios adjusted for the decision of Bank Indonesia as well as maintain its performance in order to remain trusted by customers in the economic activities. This study aims to analyze the effect of Capital Adequacy Ratio (CAR), Loan to Deposit Ratio (LDR), Non-Performing Loan (NPL), Net Interest Margin (NIM) an Operating Expenses to Operating Income Ratio (OEOI) to the Return on Assets (ROA) of bank in Indonesia listed in Indonesia Stock Exchange in the period 2007 - 2011. 25 banks are investigated and 17 of them are chosen as samples. The analysis technique of this study used in this study is multiple linear regressions to obtain a comprehensive picture of the relationship between variables that one with the other variables. In addition, the hypothesis test used was the t-test statistic for testing the partial regression coefficient and test F-statistic for testing significance together with the significance level of $5 \%$. The results of this study indicate that NPL and OEOI significantly and negatively related to ROA banking sector, CAR, LDR, and the NIM has non-significant impact on ROA in banking sector. The results of this study is expected that the variable CAR, LDR, NPL, NIM, and OEOI can used as guidelines for the management of banks in managing a bank in order to become a healthy bank.
\end{abstract}

Keywords Capital Adequacy Ratio (CAR), Loan to Deposit Ratio (LDR), Non-Performing Loan (NPL), Net Interest Margin (NIM), Operating Expense to Operating Income Ratio (OEOI) and Return on Assets (ROA)

\section{Introduction}

Multi-dimensional crisis created significant impact on Indonesia's economic climate, particularly in the banking sector. These conditions have occurred in Indonesia in 1997 to 1998 where a number of banks were liquidated and merged. The world economic situation in 2008 also had an impact on Indonesia. The economic crisis in the United States in 2008 indicated by the collapse of several large financial institutions in the United States (US) and United Kingdom (UK) influenced the economy of Indonesia though it was relatively limited. The same thing happened in Europe, specifically, Greece economic crisis has not yet been resolved resulting in an unstable global economy.

The economy is essentially inseparable from banking industry. Business activity is always related to funding issues. Bank is one institution that acts as a financial intermediary between those who have the funds (surplus funds) to the other - the party that needs funds (deficit fund), as well as an institution that serves expedite payment traffic.

Indonesia adopts an open economy that affect the world financial turmoil, especially in the financial sector that basically cannot be separated from the world of banking.

The philosophy that underlies the business of banks is the belief of the society (customers). As an institution of trust in its operations, the bank must always maintain its performance as a function of the value of the company, if the performance of the company increases, the value will be higher; it will be followed by an increase in stock prices as a form of enhancing company performance. But otherwise if there is a poor perception about the bank's performance will be followed by the decline in stock prices due to the loss of confidence in the bank. This is the basis why the stock price change is relevant to the performance of the company.

Bank not only serves as a store and the lender, but also creates the means of payment, monetary stability, and dynamic economic growth of a country. Bank encourages international trade economic relations between countries in the world. Banks with good performance will attract investors to invest in the banking sector, as investors saw the healthy performance of the bank, the bank's management is good, so as to provide an adequate return for investors.

Understanding bank according to Law No. 10 of 
1998 as follows: Business entities that raise funds from the public in the form of deposits and to the community in the form of credit and / or form - the form of the other in order to improve the lives of the common people"

The crisis that has engulfed the global economy this time had little influence on the economy of Indonesia. At the beginning of the fourth quarter of 2008, Indonesia's Economy faces a busy time - during a tense exchange rate of foreign currencies rose sharply. Then tighten liquidity in the banking system, especially foreign banks, by attracting customer funds with an interest rate higher than the prevailing market rate. Therefore contributes to the local banks with the number of its customers to move funds into the foreign bank, it is perceived by the end of first quarter of 2009.

Banking stability kept awake until the first quarter of 2009. This provides an atmosphere conducive to the development of the real sector in Indonesia. While most countries in the world have experienced economic contraction more severe and prolonged, but the economy of Indonesia was still able to show encouraging development.

The performance of a bank can be seen from the soundness of the bank. Bank soundness is a qualitative and quantitative assessment of various aspects affecting the condition or performance of a bank through assessments on capital, asset quality, management, earnings, liquidity and sensitivity to market risk. The development of a dynamic assessment of the condition of the bank so that the bank's rating system should reflect the condition of the bank at the moment and in the future.

Key developments in the bank's assessment of the health or the health of financial and non-financial conditions of banks are related to the interest of all parties: owners, managers, and users community bank, Bank Indonesia as the bank regulatory authorities, and other parties. The condition can be used by the bank - the bank's performance is evaluated separately in applying the precautionary principle - attention (prudent banking), compliance with applicable regulations and risk management.

Main Indicator Banking Sector in Indonesia for period $2007-2011$

Table 1. Main Indicator banking Sector in Indonesia Period 2007 - 2011 (in \%)

\begin{tabular}{|c|c|c|c|c|c|}
\hline Main Indicator & 2007 & 2008 & 2009 & 2010 & 2011 \\
\hline Return On Assets (ROA) & 2.8 & 2.3 & 2.6 & 2.9 & 3.0 \\
\hline $\begin{array}{c}\text { Capital Adequacy Ratio } \\
\text { (CAR) }\end{array}$ & 19.3 & 16.8 & 17.4 & 17.2 & 16.1 \\
\hline $\begin{array}{c}\text { Loan to Deposit Ratio } \\
\text { (LDR) }\end{array}$ & 66.3 & 74.6 & 72.9 & 75.5 & 79.0 \\
\hline $\begin{array}{c}\text { Non-Performing Loans } \\
\text { (NPL) }\end{array}$ & 4.1 & 3.2 & 3.3 & 2.6 & 2.2 \\
\hline $\begin{array}{c}\text { Net Interest Margin } \\
\text { (NIM) }\end{array}$ & 5.7 & 5.7 & 5.6 & 5.7 & 5.9 \\
\hline $\begin{array}{c}\text { Operating Expense to } \\
\text { Operating Income (OEOI) }\end{array}$ & 84.1 & 88.6 & 86.6 & 86.1 & 85.4 \\
\hline
\end{tabular}

Source: Economic Review Journal Bank Indonesia (2011)

\section{Background of the Study}

Bank's capital is not managed properly can lead to risk in the form of loan repayment is not smooth or otherwise called non-performing loans (NPL) that will affect the performance of the bank example occurred in Indonesia Bank Executive, Bank Indonesia (BI) provides extension of the completion of non-performing loans with the entry of new owners with limited public offering (rights issue) to put the fund of IDR 180 billion, resulting in NPL in the top 5\%.

The increase in NPL resulted in delays in credit. Bank Indonesia determines NPL rate of 5\%. If banks can reduce NPL below $5 \%$ of the potential benefits to be obtained will be great because it will save the funds needed to establish a reserve loans.

Reserves for losses to non-performing loans in the utilization of productive assets owned. By making use of productive assets, the bank earns income through the calculation of Net Interest Margin (NIM). It is a financial ratio that shows the bank's ability to generate earnings by utilizing productive assets owned.

Bank Indonesia plans to set up a standard NIM. For in Asia Indonesia is a country that has the biggest NIM is 6\%, the ratio should ideally range between levels of $3-5 \%$. The high NIM in Indonesia because the customer is charged the cost should be borne by the bank.

To reduce the risk of financing, Bank Indonesia set a loan to deposit ratio (LDR), which is the ratio of the total amount of loans to the amount of capital plus the amount of third party funds that have been collected. LDR is a liquidity ratio of bank health. The higher this ratio, the lower the ability of the concerned bank liquidity allowing a bank in error will be greater.

Under the terms of the Bank Indonesia Circular Letter No. 26/5/BPPP dated May 29, 1993 the amount of the Loan to Deposit Ratio in conventional or Financing to Deposit Ratio (FDR) and the liquidity of Islamic banks which reflects a healthy bank is $85 \%-110 \%$.

Bank Indonesia will set a cut-Loan to Deposit Ratio (LDR) and statutory reserves of the new bank. Bank Indonesia expects this move could push the bank's role as intermediary. Bank Indonesia hopes the move will push credit growth of $20 \%$. Bank Indonesia recorded loan growth in the second week of April 2009 notes lending reached IDR 169.3 trillion, so credit growth to positive $1.17 \%$ (www.metrotvnews.com).

Liquidity problems of banks provide a great impact. The issue of the flow of foreign funds that are temporary and can be withdrawn under unfavorable conditions (hot money) getting rolling such as foreign funds in the stocks, Government Bonds (Surat Utang Negara, SUN) and Certificates Bank Indonesia (Sartifikat Bank Indonesia, SBI). The government has yet to restrict foreign funds and domestic funds have not been prioritizing. Meanwhile, Indonesian banks have enough liquidity funds worth IDR 400 trillion (www.metrotvnews.com). 
The Capital Adequacy Ratio (CAR) on the bank in accordance with the rules in force in Indonesia is determined by the amount of capital owned consists of core capital and supplementary capital, is one of Bank Indonesia's policy of mandatory or require banks to provide minimum capital percentage certain of Risk Weighted Assets (RWA).

Besides Adequacy Capital Ratio (CAR), Non-Performing Loan (NPL), Net Interest Margin (NIM) and the Loan to Deposit Ratio (LDR), the level of profitability is also an important factor in assessing the health of the bank. Profitability reflects the bank's ability to generate earnings effectively and efficiently. The development of banking profits earned can be known through the bank's financial statements. Bank profitability measured using Return on Assets (ROA) this is due to the ability of the bank's profitability will depend on the ability of bank management in managing existing assets and liabilities.

Health or financial condition in the interest of all parties concerned owners, managers (bank management), public service users, Bank Indonesia as the authority, and the other banks. The condition of the bank can be used by the - party to evaluate the bank's performance in implementing the precautionary principle - attention (prudential), compliance with applicable regulations and risk management (risk management). Based on BI Regulation No. 6/10/PBI/2004 definition of the soundness of the bank is as follows:

"The health of banks is judging quantitative results on various aspects affecting the condition or performance of a bank through an assessment or judging of quantitative and qualitative factors factors, capital, asset quality, management, earnings, liquidity and sensitivity to market risk"

Bank soundnesscan be judgedfromseveral indicatorssuch as:

1. The financial statements of the bank based on the financial statements are used to calculate several financial ratios commonly used as the basis of assessment of the soundness of the bank.

2. Financial Ratio Analysis allows management to identify changes - changes in the underlying trend and the number of relationships and the reasons for those changes. The results of the financial analysis will help interpret key relationships and trends that can provide basic considerations regarding the potential success of the company in the future.

Allocation of funds by banks not only to lend to the public, but is also used for investment or investment funds in other productive assets, i.e. letter of securities such as bonds and Certificates Bank Indonesia (SBI) in order to strengthen bank liquidity, investments into other enterprises and placement as a liquid. Loan to deposit ratio (LDR) is a ratio used to assess a bank's liquidity by dividing the number of loans granted by banks to grant a third party. The higher this ratio, the lower the ability of bank liquidity is concerned that the possibility of a bank in error will be greater.
Operating Expenses to Operating Income ratio (OEOI) is to compare the operating costs with the income, the lower this ratio, the higher performance management, because it is more efficient use of existing resources in the bank. OEOI ratio that can be tolerated by Bank Indonesia amounted to 93.52\% (SlametRiyadi, 2006; 159). The main activities of the bank are as intermediaries, operating costs and revenues are dominated by interest expense and interest income (Dendawijaya, 2009: 98)

In this study, the authors calculate the level of profitability by using the Return On Assets (ROA) this is due to the bank's ability to generate earnings will depend on the ability of bank management in managing existing assets with liabilities.

Based on the above authors conducted a study on the Effect of Capital Adequacy Ratio (CAR), Non-Performing Loan (NPL), Net Interest Margin (NIM), Loan to Deposit Ratio (LDR) and Operating Expenses to Operating Income ratio (OEOI) against the Bank toward above par performance (ROA).

\section{Theoretical Framework}

This study aims to examine the value relevance of bank performance measurements, which are indicated by major banking performance ratios (CAR, LDR, NPL, NIM, OEOI and ROA) as well as earnings and economic conditions.

(1) CAR (Capital Adequacy Ratio) is the ratio of bank's capital required to cover risks losses arising from investment that contain market and credit risk. All banks in Indonesia are required to provide a minimum capital of $8 \%$ of Capital Adequacy Ratio by Circular Letter Bank Indonesia No.6/23/DPNP May 31, 2004. Effect of CAR on the value of banking firms can be explained by the signaling theory and the efficient market theory.

CAR is an indicator that shows the ability of available bank's equity covers the declining in bank assets due to providing funds to accommodate the purposes of business development and risk of loss funds caused by the operations of the bank. The higher CAR shows that a bank has greater equity to cover risks that may affect to the amount of bank capital, it implies the better the condition of a bank, hence increases investor confidence in the banking company (Ponco, 2008). Investor confidence will have an effect on their valuation process.

(2) LDR (Loan to Deposit ratio) shows how a bank has tied its deposit in less liquid assets. It is a ratio to assess the liquidity risk of a bank. Liquidity risk is an inability of banks to pay back withdrawals by depositors by relying on credit provided as a source of liquidity.

LDR can be used to assess the management strategy of a certain bank. The higher Loan to Deposit Ratio shows more risky bank liquidity conditions, while lower LDR shows a lack of effectiveness of the bank in channeling its bank loans which means loss of opportunity to gain profit (Purwasih, 2010). 
Effective liquidity management should confirm to public that the bank is safety and able to pay its obligation (confidence factor). Bank with effective liquid management provide safety and a sense of confidence to their investors which could be classified as good news to market while highly illiquid is classified as bad news to investors as bank with no confidence is sentence to failure. (Dimitropoulos, 2010).

The higher LDR ratio means the lower ability of a bank in its liquidity which will decrease investor confidence and have a negative effect on their valuation process. (Wirnkar\&Tanko, 2008). Bank Indonesia suggests maximum $100 \%$ LDR to meet the criteria of health bank.

(3) NPL (Non-Performing Loans) can be defined as a loan repayment difficulties due presence of factors beyond the control of debtor. This ratio indicates the asset quality ratio, it measure the ability of bank management in managing their credit (Nurhartanto, 2010). According to Bank Indonesia Regulation Number 6/10/PBI/2004 dated April 12, 2004 on Rating System Health Commercial Bank confirmed that NPL above 5\% are considered "unhealthy" bank. NPL ratio calculates the level of non-performing loan compared to its total loan. The higher the value of NPL ratio shows that greater non-performing loan compared to total loan. It implies a worse credit management by the banks (Wirnkar\&Tanko, 2008).

Hence, it will decrease investor confidence in the banking company which will have a negative effect on their valuation process.

According to BI Regulation No.5/8 in 2003, market risk is the type of risks that exist in the banking industry. Market risk is the combined risk that is formed by changes in interest rates, changes in exchange rates and factors that determine stock market prices, or equity, and commodities.

(4) NIM (Net Interest Margin) Bank Indonesia suggests minimum NIM ratio should be above $1.50 \%$ to meet the criteria of health bank. Net Interest Margin (NIM) is an earning aspect ratio that shows bank management capability in managing its productive assets to generate net interest income. Net interest income derived from Interest income less interest expense.

The greater this ratio means there is an increase in interest income on earning assets managed by banks. So the greater Net Interest Margin (NIM) ratio means the greater the bank's profitability obtained by the bank, which means that the bank performance has improved, which will positively impact their valuation process (Poncho, 2008).

(5) Operating Expenses to Operating Income (OEOI) is the ratio between operating expenses with operating income, the lower the ratio OEOI bank management performance will be better. According to banking regulations in Indonesia OEOI ratio amounted to $93.52 \%$. The operational costs of banks and bank operating income are dominated by interest expense and interest income (Dendawijaya, 2009.98).

Profitability reflects the bank's ability to generate earnings effectively and efficiently. The development of banking profits earned can be known through the bank's financial statements.

Bank profitability measured using Return on Assets (ROA) this is due to the ability of the bank's profitability will depend on the ability of bank management in managing existing assets and liabilities.

Health or financial condition in the interest of all parties concerned owners, managers (bank management), public service users, Bank Indonesia as the authority, and the other banks. The condition of the bank can be used by the - party to evaluate the bank's performance in implementing the precautionary principle - attention (prudential), compliance with applicable regulations and risk management.

Based on BI Regulation No. 6/10/PBI/2004 definition of the soundness of the bank is as follows:

"The health of banksisjudgingquantitativeresultson variousaspects affecting thecondition orperformance of abankthrough an assessmentorjudging quantitative andqualitativefactors -factors, capital, and quality of theirassets, management, earnings, liquidityand sensitivity tomarket risk"

Bank soundnesscan be judgedfromseveral indicatorssuch as:

1 The financial statements of the Bank based on financial statements showing will be calculated several financial ratios commonly used as the basis of assessment of the soundness of the bank.

2 Financial Ratio Analysis Allows management to identify changes - changes the amount of principal in trend and the relationships and the reasons for those changes. The results of the financial analysis will help interpret key relationships and trends that can provide basic considerations regarding the potential success of the company in the future. 


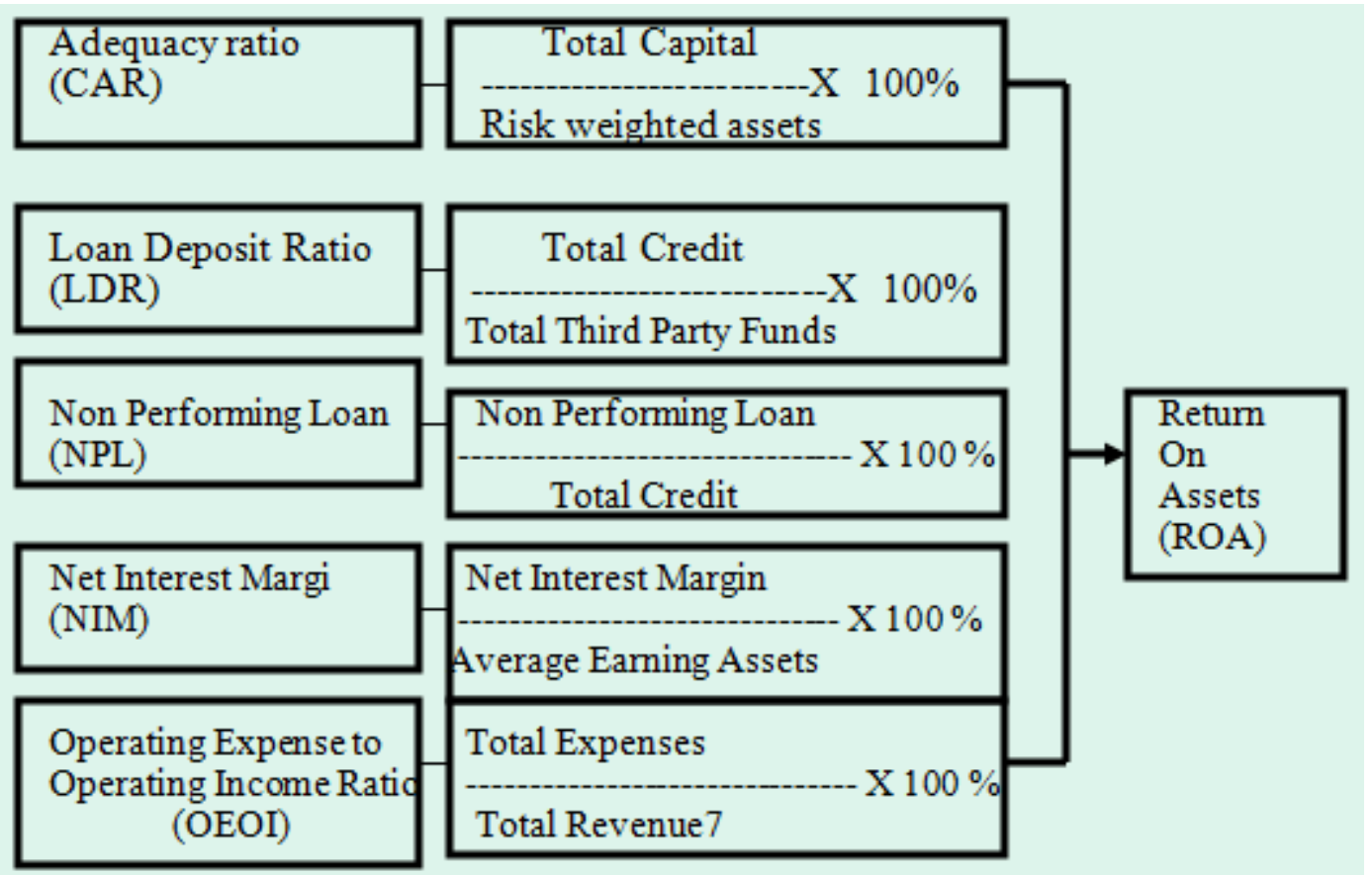

Research Hypotheses are as follows:

1. CAR significant positive effect on ROA

2. LDR significant positive effect on ROA

3. NPL significant negative effect on ROA

4. NIM significant positive effect on ROA

5. OEOI significant negative effect on ROA

6. CAR, LDR, NPL, NIM AND OEOI simultaneous effect on ROA

\section{Research Methods}

1. Descriptive Statistics, to provide an overview of the object under study through a data sample as is,without doing analysis and making conclusions apply to the public (Sugiyono, 2010: 29) in this case is to calculate the mean, minimum and maximum of panel data.

2. Regression Analysis, to see the effect of the relationship between independent variables on theDependent variable using a multiple linear regression analysis using the formula:

$\mathrm{ROA}=\mathrm{a}+\beta_{1} \mathrm{CAR}+\beta_{2} \mathrm{LDR}-\beta_{3} \mathrm{NPL}+\beta_{4} \mathrm{NIM}-\beta_{5} \mathrm{OEOI}+\varepsilon$

Note : $\mathrm{a}=$ Constant

$\beta_{1}=$ regression coefficient for CAR

$\beta_{2}=$ regression coefficient for LDR

$\beta_{3}=$ regression coefficient for NPL

$\beta_{4}=$ regression coefficient for NIM

$\beta_{5}=$ regression coefficient for OEOI

$\varepsilon=$ standard error

The relationship between independent variables with the dependent variable using panel data modeling is the incorporation of cross section data and time series that has dimensions of space and time as well.
Estimation techniques panel data regression model, there are three models, namely the model Fixed Effect, Random Effect, and OLS (common). The technique is as follows:

Fixed Effect significance test (Test Chow)

Assumes that the individual (company) has the intercept but have the same slope. To test this model is done by using the likelihood ratio with significant level of $5 \%(\alpha=0.05)$,

\section{Hypothesis $\mathrm{H}_{0}$ : OLS}

Ha: FE

Decision-making criteria if:

1. probability ( $\mathrm{p}$-value) cross-section chi-square $\leq 0.05 \mathrm{H}_{0}$ rejected

2. probability ( $\mathrm{p}$-value) cross-section chi-square $>0.05$ $\mathrm{H}_{0}$ accepted

Or:

1. probability ( $\mathrm{p}$-value) cross-section $\mathrm{F} \leq 0.05$ Ho rejected

2. probability (p-value) cross-section $\mathrm{F}>0.05$ Ho accepted

a Significant test Random Effect

To determine whether the model is better than the Random Effect OLS model used Lagrange test Multiplier (LM) hypotheses used in this test is as follows:

Ho: OLS

Ha: RE (Random effect)

If the value LM statistic greater critical value of chi-squares statistic, the null hypothesis is rejected.

b Significant Fixed Effect or Random Effect

Hausman developed a statistical test to choose whether to use the model Fixed Effect or Random Effect, the hypothesis 
used is as follows:

Ho: RE (random effect)

Ha: FE (Fixed effect) If probability $<\alpha=5 \%$ then Ho is rejected.

\section{Hypothesis Testing}

- $\quad \mathrm{F}$ test is done to see with the same independent variables affect the Dependent variable.

- $\mathrm{T}$ test was conducted to determine the effect of the independent variable (CAR,LDR, NPL, NIM and OEOI) the dependent variable (ROA)

\section{Test Coefficient Determination}

To determine the influence of the independent variable on the dependent variable is when $\mathrm{R}^{2}$ is close to $100 \%$, then the calculation results show that the better or more precise regression line obtained.

Based on the table 1 mean CAR is at $16.36 \%$. Only 6 banks were above average remaining below the average. But still above average as determined by Bank Indonesia at $8 \%$. Maximum CAR of $46.49 \%$ in BKSW in 2011, and minimum CAR of $9.92 \%$ in BKSW in 2010 .

Table 2. CAR 2007-2011

\begin{tabular}{|c|c|c|c|c|c|c|c|c|c|}
\hline \multirow{2}{*}{ INDEX } & \multirow{2}{*}{ EMITEN } & \multicolumn{5}{|c|}{ TAHUN } & \multirow{2}{*}{ Mean } & \multirow{2}{*}{ Max } & \multirow{2}{*}{ Min } \\
\hline & & 2007 & 2008 & 2009 & 2010 & 2011 & & & \\
\hline INPC & ArthaGrahaInternational & 12.18 & 14.90 & 13.77 & 13.65 & 12.65 & 13.43 & 14.90 & 12.18 \\
\hline BBKP & Bukopin & 12.84 & 11.20 & 14.36 & 13.02 & 14.33 & 13.15 & 14.36 & 11.20 \\
\hline $\mathrm{BBCA}$ & Central Asia & 19.20 & 15.80 & 15.30 & 13.50 & 12.70 & 15.30 & 19.20 & 12.70 \\
\hline BNGA & CIMB Niaga & 17.05 & 15.60 & 13.88 & 13.47 & 13.16 & 14.63 & 17.05 & 13.16 \\
\hline BDMN & Danamon Indonesia & 20.30 & 15.40 & 20.70 & 16.00 & 17.50 & 17.98 & 20.70 & 15.40 \\
\hline SDRA & Himpunan Saudara 1906 & 15.00 & 13.00 & 13.76 & 19.69 & 13.38 & 14.97 & 19.69 & 13.00 \\
\hline BABP & ICB Bumiputra & 11.86 & 11.78 & 11.19 & 12.55 & 10.47 & 11.57 & 12.55 & 10.47 \\
\hline BNII & International Indonesia & 19.81 & 19.52 & 14.71 & 12.74 & 12.03 & 15.76 & 19.81 & 12.03 \\
\hline MAYA & Mayapada Internasional & 29.95 & 23.69 & 17.05 & 20.40 & 14.68 & 21.15 & 29.95 & 14.68 \\
\hline MEGA & Mega & 14.21 & 16.16 & 18.84 & 14.78 & 11.70 & 15.14 & 18.84 & 11.70 \\
\hline BBNP & Nusantara Parahyangan & 17.00 & 14.04 & 12.56 & 12.76 & 13.45 & 13.96 & 17.00 & 12.56 \\
\hline NISP & OCBC NISP & 19.30 & 16.80 & 17.40 & 17.20 & 16.10 & 17.36 & 19.30 & 16.10 \\
\hline BSWD & Of India Indonesia & 20.64 & 33.27 & 32.90 & 26.91 & 23.19 & 27.38 & 33.27 & 20.64 \\
\hline BNLI & Permata & 13.30 & 10.80 & 12.20 & 14.10 & 14.10 & 12.90 & 14.10 & 10.80 \\
\hline AGRO & Rakyat Indonesia Agroniaga & 17.27 & 12.58 & 19.63 & 14.42 & 16.39 & 16.06 & 19.63 & 12.58 \\
\hline PNBN & PAN Indonesia & 21.58 & 20.31 & 21.53 & 16.65 & 17.45 & 19.50 & 21.58 & 16.65 \\
\hline BKSW & QNB Kesawan & 10.36 & 10.43 & 12.56 & 09.92 & 46.49 & 17.95 & 46.49 & 9.92 \\
\hline & Mean & 17.17 & 16.19 & 16.61 & 15.40 & 16.46 & 16.36 & & \\
\hline & Maximum & 29.95 & 33.27 & 32.90 & 26.91 & 46.49 & & 46.49 & \\
\hline & Minimum & 10.36 & 10.43 & 11.19 & 09.92 & 10.47 & & & 09.92 \\
\hline
\end{tabular}

Source: http://www.idx.co.id 
Table 3. LDR $2007-2011$

\begin{tabular}{|c|c|c|c|c|c|c|c|c|c|}
\hline \multirow{2}{*}{ INDEX } & \multirow{2}{*}{ EMITEN } & \multicolumn{3}{|c|}{ TAHUN } & \multirow{2}{*}{ Mean } & \multirow{2}{*}{ Max } & \multirow{2}{*}{ Min } \\
\cline { 2 - 7 } & & 2007 & 2008 & 2009 & 2010 & 2011 & & \\
\hline INPC & Artha Graha International & 82.22 & 93.47 & 84.04 & 76.13 & 82.21 & 83.61 & 93.47 & 76.13 \\
\hline BBKP & Bukopin & 65.26 & 83.60 & 75.99 & 71.85 & 85.01 & 76.34 & 85.01 & 65.26 \\
\hline BBCA & Central Asia & 43.60 & 53.80 & 50.30 & 55.20 & 61.70 & 59.92 & 61.70 & 43.60 \\
\hline BNGA & CIMB Niaga & 79.30 & 87.84 & 95.11 & 88.04 & 94.41 & 89.94 & 95.11 & 79.30 \\
\hline BDMN & Danamon Indonesia & 88.10 & 86.40 & 88.80 & 93.80 & 98.30 & 91.08 & 98.30 & 86.40 \\
\hline SDRA & Himpunan Saudara 1906 & 93.87 & 102.20 & 94.94 & 100.20 & 81.70 & 94.58 & 102.20 & 81.70 \\
\hline BABP & ICB Bumiputra & 84.50 & 90.44 & 89.64 & 84.96 & 84.93 & 86.89 & 90.44 & 84.50 \\
\hline BNII & International Indonesia & 88.01 & 86.53 & 82.93 & 89.03 & 95.07 & 88.31 & 95.07 & 82.93 \\
\hline MAYA & Mayapada Internasional & 103.88 & 100.22 & 83.77 & 78.38 & 82.10 & 89.67 & 103.88 & 78.38 \\
\hline MEGA & Mega & 46.74 & 64.67 & 56.82 & 56.03 & 63.75 & 57.60 & 64.67 & 46.74 \\
\hline BBNP & Nusantara Parahyangan & 49.39 & 66.12 & 73.64 & 80.41 & 84.92 & 70.90 & 84.92 & 49.39 \\
\hline NISP & OCBC NISP & 66.30 & 74.60 & 72.90 & 75.20 & 78.80 & 73.56 & 78.80 & 66.30 \\
\hline BSWD & Of India Indonesia & 62.16 & 83.11 & 81.10 & 87.36 & 85.71 & 79.89 & 87.36 & 62.16 \\
\hline BNLI & Permata & 88.00 & 81.80 & 90.60 & 87.50 & 83.10 & 86.20 & 90.60 & 81.80 \\
\hline AGRO & Rakyat Indonesia Agroniaga & 77.02 & 94.36 & 80.99 & 86.68 & 65.79 & 80.97 & 94.36 & 65.79 \\
\hline PNBN & PAN Indonesia & 92.36 & 78.93 & 73.31 & 74.22 & 80.36 & 79.84 & 92.36 & 73.31 \\
\hline BKSW & QNB Kesawan & 68.46 & 74.66 & 66.67 & 71.65 & 75.48 & 71.44 & 75.48 & 66.97 \\
\hline & Mean & 75.25 & 82.51 & 78.93 & 79.80 & 81.37 & 79.57 & & \\
\hline & Maximum & 103.88 & 102.20 & 95.11 & 100.20 & 98.30 & & 103.88 & \\
\hline & Minimum & 43.60 & 53.80 & 50.30 & 55.20 & 61.70 & & & 43.60 \\
\hline
\end{tabular}

Source: http://www.idx.co.id

Based on the table 2 the mean of LDR is equal to $79.57 \%$, only 6 banks below average. Whereas the LDR Maximum value of $103.88 \%$ in MAYA in 2007 and the minimum value is equal to $43.60 \%$ LDR in BBCA bank in 2007 according to the standards issued by Bank Indonesia maximum LDR is $100 \%$

Table 4. NPL $2007-2011$

\begin{tabular}{|c|c|c|c|c|c|c|c|c|c|}
\hline \multirow{2}{*}{ INDEX } & \multirow{2}{*}{ EMITEN } & \multicolumn{5}{|c|}{ TAHUN } & \multirow{2}{*}{ Mean } & \multirow{2}{*}{ Max } & \multirow{2}{*}{ Min } \\
\hline & & 2007 & 2008 & 2009 & 2010 & 2011 & & & \\
\hline INPC & Artha Graha International & 2.55 & 2.70 & 2.83 & 2.00 & 1.85 & 2.39 & 2.83 & 1.85 \\
\hline BBKP & Bukopin & 3.57 & 4.87 & 2.81 & 3.22 & 2.88 & 3.47 & 4.87 & 2.81 \\
\hline $\mathrm{BBCA}$ & Central Asia & 0.80 & 0.60 & 0.70 & 0.60 & 0.50 & 0.64 & 0.80 & 0.50 \\
\hline BNGA & CIMB Niaga & 3.03 & 2.50 & 3.06 & 2.59 & 2.64 & 2.76 & 3.06 & 2.50 \\
\hline BDMN & Danamon Indonesia & 2.30 & 2.30 & 4.50 & 3.00 & 2.50 & 2.92 & 4.50 & 2.30 \\
\hline SDRA & Himpunan Saudara 1906 & 1.18 & 1.17 & 1.29 & 1.78 & 1.65 & 1.41 & 1.78 & 1.17 \\
\hline BABP & ICB Bumiputra & 6.10 & 5.64 & 5.63 & 4.34 & 6.25 & 5.59 & 6.25 & 4.34 \\
\hline $\mathrm{BNII}$ & International Indonesia & 2.92 & 3.20 & 2.42 & 3.09 & 2.13 & 2.75 & 3.20 & 2.13 \\
\hline MAYA & Mayapada Internasional & 0.14 & 2.07 & 0.49 & 2.01 & 1.51 & 1.24 & 2.07 & 0.14 \\
\hline MEGA & Mega & 1.53 & 1.18 & 1.70 & 0.90 & 0.98 & 1.26 & 1.70 & 0.90 \\
\hline BBNP & Nusantara Parahyangan & 1.48 & 1.12 & 1.81 & 0.63 & 0.78 & 1.16 & 1.81 & 0.63 \\
\hline NISP & OCBC NISP & 4.10 & 3.20 & 3.30 & 2.60 & 2.20 & 3.08 & 4.10 & 2.20 \\
\hline BSWD & Of India Indonesia & 1.95 & 2.16 & 1.82 & 3.55 & 1.98 & 2.29 & 3.55 & 1.82 \\
\hline BNLI & Permata & 1.50 & 1.20 & 1.50 & 2.70 & 2.00 & 1.78 & 2.70 & 1.20 \\
\hline AGRO & Rakyat Indonesia Agroniaga & 4.67 & 3.36 & 4.48 & 1.84 & 1.52 & 3.17 & 4.67 & 1.52 \\
\hline PNBN & PAN Indonesia & 3.06 & 4.34 & 3.16 & 4.37 & 3.56 & 3.70 & 4.37 & 3.06 \\
\hline BKSW & QNB Kesawan & 6.33 & 3.74 & 5.33 & 1.91 & 0.82 & 3.63 & 6.33 & 0.82 \\
\hline & Mean & 2.78 & 2.67 & 2.75 & 2.42 & 2.10 & 2.54 & & \\
\hline & Maximum & 6.33 & 5.64 & 5.63 & 4.37 & 6.25 & & 6.33 & \\
\hline & Minimum & 0.14 & 0.60 & 0.49 & 0.60 & 0.50 & & & 0.14 \\
\hline
\end{tabular}

Source: http://www.idx.co.id

Based on table 3 the mean NPL amounted to 2.54\%. only 8 banks that its NPLs are under the mean. Maximum value of NPLs amounted to $6.33 \%$ on bank BKSW in 2007 and is a value above the limit set by Bank Indonesia in the amount of 5\%. NPL minimum of $0.14 \%$ in the bank MAYA 2007. 
Table 5. NIM $2007-2011$

\begin{tabular}{|c|c|c|c|c|c|c|c|c|c|}
\hline \multirow{2}{*}{ INDEX } & \multirow{2}{*}{ EMITEN } & \multicolumn{5}{|c|}{ TAHUN } & \multirow{2}{*}{ Mean } & \multirow{2}{*}{$\operatorname{Max}$} & \multirow{2}{*}{ Min } \\
\hline & & 2007 & 2008 & 2009 & 2010 & 2011 & & & \\
\hline INPC & Artha Graha International & 3.67 & 3.74 & 3.81 & 3.97 & 3.55 & 3.75 & 3.97 & 3.55 \\
\hline BBKP & Bukopin & 4.27 & 4.80 & 4.07 & 4.75 & 4.55 & 4.49 & 4.80 & 4.07 \\
\hline $\mathrm{BBCA}$ & Central Asia & 6.10 & 6.60 & 6.40 & 5.30 & 5.70 & 6.02 & 6.60 & 5.30 \\
\hline BNGA & CIMB Niaga & 6.08 & 5.69 & 6.78 & 6.46 & 5.63 & 6.13 & 6.78 & 5.63 \\
\hline BDMN & Danamon Indonesia & 10.40 & 11.10 & 11.20 & 11.30 & 9.80 & 10.76 & 11.30 & 9.80 \\
\hline SDRA & Himpunan Saudara 1906 & 12.37 & 10.46 & 7.19 & 10.24 & 9.93 & 10.04 & 12.37 & 7.19 \\
\hline BABP & ICB Bumiputra & 7.00 & 5.17 & 5.78 & 5.15 & 5.43 & 5.71 & 7.00 & 5.15 \\
\hline $\mathrm{BNII}$ & International Indonesia & 5.18 & 5.59 & 6.08 & 5.86 & 5.22 & 5.59 & 6.08 & 5.18 \\
\hline MAYA & Mayapada Internasional & 6.85 & 7.57 & 6.74 & 6.25 & 5.84 & 6.65 & 7.57 & 5.84 \\
\hline MEGA & Mega & 5.06 & 5.44 & 4.94 & 4.88 & 5.40 & 5.14 & 5.44 & 4.88 \\
\hline BBNP & Nusantara Parahyangan & 3.61 & 3.60 & 3.69 & 4.91 & 4.99 & 4.16 & 4.99 & 3.60 \\
\hline NISP & OCBC NISP & 5.70 & 5.70 & 5.60 & 5.70 & 5.90 & 5.72 & 5.90 & 5.60 \\
\hline BSWD & Of India Indonesia & 3.72 & 5.44 & 5.41 & 5.82 & 6.39 & 5.36 & 6.39 & 3.72 \\
\hline BNLI & Permata & 7.00 & 6.20 & 5.70 & 5.30 & 5.10 & 5.86 & 7.00 & 5.10 \\
\hline AGRO & Rakyat Indonesia Agroniaga & 4.03 & 4.06 & 4.98 & 5.03 & 4.54 & 4.53 & 5.03 & 4.03 \\
\hline PNBN & PAN Indonesia & 5.81 & 4.72 & 4.76 & 4.59 & 4.64 & 4.90 & 5.81 & 4.59 \\
\hline BKSW & QNB Kesawan & 4.68 & 4.24 & 4.78 & 5.13 & 5.34 & 4.83 & 5.34 & 4.24 \\
\hline & Mean & 5.97 & 5.89 & 5.76 & 5.92 & 5.76 & 5.86 & & \\
\hline & Maximum & 12.37 & 11.10 & 11.20 & 11.30 & 9.93 & & 12.37 & \\
\hline & Minimum & 3.61 & 3.60 & 3.69 & 3.97 & 3.55 & & & 3.55 \\
\hline
\end{tabular}

Source: http://www.idx.co.id

Based on the table 4 is the mean of NIM at $5.86 \%$ only 5 banks that have NIM above the mean. NIM is a maximum of $12: 37 \%$ in SDRA in 2007 . While the NIM starts at $3: 55 \%$ in the INPC.

Table 6. OEOI $2007-2011$

\begin{tabular}{|c|c|c|c|c|c|c|c|c|c|}
\hline \multirow{2}{*}{ INDEX } & \multirow{2}{*}{ EMITEN } & \multicolumn{5}{|c|}{ TAHUN } & \multirow{2}{*}{ Mean } & \multirow{2}{*}{ Max } & \multirow{2}{*}{ Min } \\
\hline & & 2007 & 2008 & 2009 & 2010 & 2011 & & & \\
\hline INPC & Artha Graha International & 90.56 & 97.50 & 73.65 & 91.75 & 92.43 & 89.18 & 97.50 & 73.65 \\
\hline BBKP & Bukopin & 84.84 & 84.45 & 86.93 & 84.98 & 82.05 & 84.65 & 86.93 & 82.05 \\
\hline BBCA & Central Asia & 66.70 & 66.80 & 68.70 & 64.30 & 60.90 & 65.48 & 68.70 & 60.90 \\
\hline BNGA & CIMB Niaga & 78.44 & 88.26 & 82.98 & 76.80 & 76.10 & 80.52 & 88.26 & 76.10 \\
\hline BDMN & Danamon Indonesia & 47.90 & 54.10 & 49.80 & 48.70 & 51.60 & 50.42 & 54.10 & 47.90 \\
\hline SDRA & Himpunan Saudara 1906 & 80.70 & 82.42 & 85.35 & 79.30 & 80.03 & 81.56 & 85.35 & 79.30 \\
\hline BABP & ICB Bumiputra & 95.56 & 96.81 & 98.94 & 94.60 & 114.63 & 100.09 & 114.63 & 94.60 \\
\hline BNII & International Indonesia & 96.28 & 94.68 & 100.77 & 92.26 & 92.75 & 95.35 & 100.77 & 92.26 \\
\hline MAYA & Mayapada Internasional & 88.46 & 90.63 & 93.82 & 90.17 & 83.38 & 89.29 & 93.82 & 83.38 \\
\hline MEGA & Mega & 79.21 & 83.15 & 85.91 & 77.79 & 81.84 & 81.58 & 85.91 & 77.79 \\
\hline BBNP & Nusantara Parahyangan & 87.84 & 89.72 & 89.28 & 85.17 & 85.77 & 87.56 & 89.72 & 85.17 \\
\hline NISP & OCBC NISP & 84.10 & 88.60 & 86.60 & 86.10 & 85.40 & 86.16 & 88.60 & 84.10 \\
\hline BSWD & Of India Indonesia & 89.54 & 80.52 & 74.57 & 73.35 & 67.51 & 77.10 & 89.54 & 67.51 \\
\hline BNLI & Permata & 84.80 & 88.90 & 89.20 & 84.00 & 85.40 & 86.46 & 89.20 & 84.00 \\
\hline AGRO & Rakyat Indonesia Agroniaga & 100.96 & 101.47 & 97.98 & 95.97 & 91.65 & 97.61 & 101.47 & 91.65 \\
\hline PNBN & PAN Indonesia & 46.09 & 47.61 & 46.35 & 45.97 & 51.47 & 47.50 & 51.47 & 45.97 \\
\hline BKSW & QNB Kesawan & 95.16 & 102.64 & 96.46 & 95.57 & 96.67 & 97.30 & 102.64 & 95.16 \\
\hline & Mean & 82.18 & 84.60 & 82.78 & 80.40 & 81.15 & 82.22 & & \\
\hline & Maximum & 100.96 & 102.64 & 100.77 & 95.97 & 114.63 & & 114.63 & \\
\hline & Minimum & 46.09 & 47.61 & 46.35 & 45.97 & 51.47 & & & 45.97 \\
\hline
\end{tabular}


Base on Table 5 the mean of OEOI is equal to $82.2 \%$ is still below the standards set by Bank Indonesia in the amount of 93.52\%. Maximum OEOI amounted to $114.63 \%$ at BABP while OEOI Minimum amounted to $45.97 \%$ in bank PNBN no overall OEOI above stadanrd Bank Indonesia there are 6 remaining bank under the Bank Indonesia standard.

Table 7. ROA $2007-2011$

\begin{tabular}{|c|c|c|c|c|c|c|c|c|c|}
\hline \multirow{2}{*}{ INDEX } & \multirow{2}{*}{ EMITEN } & \multicolumn{5}{|c|}{ TAHUN } & \multirow{2}{*}{ Mean } & \multirow{2}{*}{ Max } & \multirow{2}{*}{ Min } \\
\hline & & 2007 & 2008 & 2009 & 2010 & 2011 & & & \\
\hline INPC & Artha Graha International & 0.29 & 0.34 & 0.44 & 0.76 & 0.72 & 0.51 & 0.76 & 0.29 \\
\hline BBKP & Bukopin & 1.63 & 1.66 & 1.46 & 1.62 & 1.87 & 1.65 & 1.87 & 1.46 \\
\hline BBCA & Central Asia & 3.30 & 3.40 & 3.40 & 3.50 & 3.80 & 3.48 & 3.80 & 3.30 \\
\hline BNGA & CIMB Niaga & 2.49 & 1.10 & 2.10 & 2.75 & 2.85 & 2.26 & 2.85 & 1.10 \\
\hline BDMN & Danamon Indonesia & 2.40 & 1.50 & 1.50 & 2.80 & 2.60 & 2.16 & 2.80 & 1.50 \\
\hline SDRA & Himpunan Saudara 1906 & 3.73 & 3.00 & 2.41 & $2 . .78$ & 3.00 & 2.98 & 3.73 & 2.41 \\
\hline BABP & ICB Bumiputra & 0.57 & 0.09 & 0.18 & 0.51 & -1.64 & -0.06 & 0.57 & -1.64 \\
\hline BNII & International Indonesia & 1.44 & 1.11 & -0.13 & 0.85 & 1.11 & 0.88 & 1.44 & -0.13 \\
\hline MAYA & Mayapada Internasional & 1.46 & 1.27 & 0.90 & 1.22 & 2.07 & 1.38 & 2.07 & 0.90 \\
\hline MEGA & Mega & 2.33 & 1.98 & 1.77 & 2.45 & 2.29 & 2.16 & 2.45 & 1.77 \\
\hline BBNP & Nusantara Parahyangan & 1.29 & 1.17 & 1.02 & 1.50 & 1.53 & 1.30 & 1.53 & 1.02 \\
\hline NISP & OCBC NISP & 2.80 & 2.30 & 2.60 & 2.90 & 3.00 & 2.72 & 3.00 & 2.30 \\
\hline BSWD & Of India Indonesia & 1.20 & 2.53 & 3.53 & 2.93 & 3.66 & 2.77 & 3.66 & 1.20 \\
\hline BNLI & Permata & 1.90 & 1.70 & 1.40 & 2.00 & 1.70 & 1.74 & 2.00 & 1.40 \\
\hline AGRO & Rakyat Indonesia Agroniaga & -0.15 & -0.11 & 0.18 & 0.67 & 1.39 & 0.40 & 1.39 & -0.15 \\
\hline PNBN & PAN Indonesia & 3.14 & 1.75 & 1.78 & 1.76 & 2.02 & 2.09 & 3.14 & 1.75 \\
\hline BKSW & QNB Kesawan & 0.35 & 0.23 & 0.30 & 0.17 & 0.46 & 0.30 & 0.46 & 0.17 \\
\hline & Mean & 1.77 & 1.47 & 1.46 & 1.83 & 1.91 & 1.69 & & \\
\hline & Maximum & 3.73 & 3.40 & 3.53 & 3.50 & 3.80 & & 3.80 & \\
\hline & Minimum & -0.15 & -0.11 & -0.13 & 0.17 & -1.64 & & & -1.64 \\
\hline
\end{tabular}

Source: http://www.idx.co.id

Based on the table 6 mean ROA amounted to $1.69 \%$ there are 8 banks with ROA below the mean. Maximum ROA amounted to $3.80 \%$ is on BBCA bank in 2011 and the minimum ROA amounted to $-1.64 \%$ in the bank BABP.

\section{Hypothesis Testing}

Table 8. Resume Chow Test

\begin{tabular}{llll}
\multicolumn{2}{l}{ Redundant Fixed Effects tests Test cross - section fixed effect } & \\
\hline \hline Effects Test & Statistic & DF & Prob. \\
\hline \hline Cross - section F & 17.652894 & $(16.63)$ & 0.0000 \\
Cross - section Chi - square & 144.644713 & 16 & 0.0000 \\
\hline \hline
\end{tabular}

Source: eviews' 6.0

Based on Table 7 shows the p-value cross section F of 0000 and a p-value Chi-square cross section of 0.0000 , both showed the probability of $<0.05$. Then Ho is rejected.

Table 9. Resume Hausman Test

\section{Correlated Random Effect - Hausman Test - Test cross - section random effects}

\begin{tabular}{llll}
\hline \hline Test summary & Chi-Sq. Statistic & Chi-Sq. d.f. & Probability \\
\hline \hline Cross - section random & 12.692803 & 5 & 0.0264 \\
\hline \hline
\end{tabular}


Based on Table 8 shows the value of Chi-square statistic 12.692803 ( $>$ Chi-square table) and the probability of random cross-section of $0.0264(<0.05)$, it can be concluded that the Ho is rejected so that the right model is used to analyze the effect of CAR, LDR, NPLs , NIM and ROA is OEOI against the fixed effect model.

\section{Panel Data Regression Equation}

Table 10. Fixed effect Model

\begin{tabular}{|c|c|c|c|c|}
\hline \multicolumn{5}{|c|}{ Cross - sections included: 17} \\
\hline Variable & Coefficient & standard error & & \\
\hline$\overline{\mathrm{C}}$ & 7.307562 & 1.241012 & 5.888389 & 0.0000 \\
\hline CAR? & -0.002067 & 0.009441 & -0.218963 & 0.8274 \\
\hline LDR? & 0.005249 & 0.005213 & 1.006896 & 0.3178 \\
\hline NPL? & -0.108113 & 0.050357 & -2.146946 & 0.0357 \\
\hline NIM? & 0.100852 & 0.059157 & 1.704821 & 0.0932 \\
\hline OEOI? & -0.076836 & 0.012613 & -6.091825 & 0.0000 \\
\hline \multicolumn{5}{|l|}{ Fixed effects (Cross) } \\
\hline INPC $-\mathrm{C}$ & -0.476732 & _MAYA-C & -0.025906 & \\
\hline $\mathrm{BBKP}-\mathrm{C}$ & 0.393543 & MEGA-C & 0.470835 & \\
\hline $\mathrm{BBCA}-\mathrm{C}$ & 0.419533 & $\mathrm{BCIC}-\mathrm{C}$ & 0.084864 & \\
\hline $\mathrm{BNGA}-\mathrm{C}$ & 0.381111 & $\mathrm{BBNP}-\mathrm{C}$ & 1.438458 & \\
\hline $\mathrm{BDMN}-\mathrm{C}$ & -2.483929 & - $\mathrm{NISP}-\mathrm{C}$ & 0.731188 & \\
\hline SDRA-C & 0.618117 & BSWD-C & 0.251270 & \\
\hline $\mathrm{BABP}-\mathrm{C}$ & -0.078347 & $\mathrm{BNLI}-\mathrm{C}$ & 0.082718 & \\
\hline BNII-C & 0.197724 & AGRO-C & -2.041568 & \\
\hline & & $\mathrm{PNBN}-\mathrm{C}$ & 0.037123 & \\
\hline \multicolumn{5}{|c|}{ Effects Specification } \\
\hline$\overline{\text { R-squared }}$ & 0.925188 & \multirow{3}{*}{$\begin{array}{l}\text { Mean dependent vari } \\
\text { Durbin-Waston stat }\end{array}$} & \multicolumn{2}{|c|}{1.689765} \\
\hline F- Statistic & 37.10049 & & \multicolumn{2}{|c|}{2.179416} \\
\hline Probability (F-statistic) & 0.000000 & & & \\
\hline
\end{tabular}

Source: eviews' 6.0

Dependent Variable: ROA? Method: Pooled Least Squares Sample: 20072011 Included observations: 5

$$
\mathrm{Y}=7.307562-0.002067 \mathrm{CAR}+0.005249 \mathrm{LDR}-0.108113 \mathrm{NPL}+0.100852 \mathrm{NIM}-0.076836 \mathrm{OEOI}+\varepsilon
$$

\section{Simultaneous Test}

Table 11. Statistic Test $F$

\begin{tabular}{lllll}
\hline \hline Variable & Probability & Tariff & Decision & Sig. \\
\hline \hline $\begin{array}{l}\text { Variable } \\
\text { Independent }\end{array}$ & 0.000000 & $<0.05$ & Reject Ho & Significant \\
\hline \hline
\end{tabular}

Source: eviews' 6.0

Based on the table 10 probability value is lower than the 0.05 significance level, so the CAR, LDR, NPL, NIM and OEOI simultaneously affect the ROA amounted to 0.925188 or $92.25 \%$ and the balance of $7.75 \%$ is influenced by other factors outside the research. 


\section{Partial Test}

\section{The effect of CAR on ROA}

Eviews processing results' shows that a significant level of 0.8274 CAR higher than $\alpha$ 0:05 so thatwe can conclude H0 CAR means no significant effect on ROA.

\section{The effect of LDR on ROA}

Eviews processing results' gained a significance level of 0.3178 LDR higher than $\alpha=0: 05$, so it canbe concluded H0 accepted, it means LDR no significant effect on ROA, it can be seen that theability of banks to extend credit of a third party to the creditor no effect on bank earnings.

\section{The effect of NPLs to ROA}

Eviews processing results' shows that a significant level of NPLs amounted to 0.0357 lower than $\alpha=0: 05$ so that it can be concluded $\mathrm{HO}$ is rejected, meaning that the NPL has a significant influenceon ROA, while based on the regression equation shows that the coefficients for the variables ofNPLs worth negative, so it can be interpreted that influence given by the NPL on ROA is negative.This means that the higher the value of NPLs resulting in lower ROA.

\section{The effect of NIM to ROA}

Eviews processing results obtained significance level of 0.0932 NIM higher than $\alpha=0: 05$ H0means received so NIM no significant effect on ROA.

\section{The effect of OEOI to ROA}

Eviews processing results obtained OEOI significance level of 0000 is lower than $\alpha=0: 05$ meansOEOI have a significant influence on ROA is shown with a negative number that indicates thehigher the value the lower ROA OEOI obtained.

\section{Conclusions and Suggestions}

Based on the results of the study can be summarized as follows:

\section{Description analysis}

a. CAR mean $16.36 \%, 46.49 \%$ maximum, and a minimum of $9.92 \%$ is still above that stipulated by Bank Indonesia in the amount of $8 \%$ can be said to be a healthy bank..

b. LDR mean $79.57 \%, 103.88 \%$ maximum and minimum $43.60 \%$ means that there are banks that are not only using third party funds but using party funds or funds first and second parties in providing credit. Bank Indonesia regulation is $100 \%$.

c. NPL mean $2.54 \%$, maximum and minimum $6.33 \%, 0.14 \%$. This shows the credit on the NPL study period was very smooth and pretty good performance of the bank in lending. d. NIM 5.86\% mean maximum and minimum 3.55\%, $12: 37 \%$ which reflects the payment of interest at the agreed value of such an enormous impact on net interest income.

e. OEOI mean $82.20 \%$ maximum $114.63 \%$ and minimum $45.97 \%$ it can be said the amount of operating costs negatively influence on ROA.

f. ROA mean at foreign exchange banks amounted to $1.69 \%$

2. The results of the partial testing

a. The regression analysis between variables CAR with Variable ROA does not have a significant effect. This can be evidenced from 0.8274 probability value greater than 0.05 . So the hypothesis is accepted.

b. LDR variable regression analysis with the variable ROA has no significant influence. This is evidenced by 0.3178 probability value greater than 0.05 , so the hypothesis that the positive effect on ROA LDR unacceptable.

c. NPL variable regression analysis with the variable ROA have significant influence 0.0357 probability is smaller than 0.05 so it can be and is negative it means NPL negative effect on ROA so that the hypothesis can be accepted.

d. Results of regression between variables NIM with ROA does not have a significant effect this can be shown by 0.0932 probability value greater than 0.05 , so the hypothesis that the positive effect on ROA NIM unacceptable.

e. OEOI variable analysis results with variable ROA have significant effects that can be demonstrated with a probability value of less than 0.050 .0000 so the hypothesis that the variable OEIO positive effect on ROA is acceptable.

3. The test results simultaneously

Simultaneously obtained that CAR, LDR, NPL, NIM and OEOI significant effect on ROA, this is indicated by 0.0000 probability less than 0.05

\subsection{Suggestions}

For further research is expected to add other variables such as DER (Debt to Equity Ratio) so that it can describe other things that can affect the ROA. Also the object of a study can be expanded, for example a bank or The Government Bank or Private Banks, Rural Banks or Islamic Bank.

1. For Exchange Bank is expected to maintain the ratio of research ratio in accordance with the regulations of Bank Indonesia so it can be considered a healthy bank.

2. For Investors can choose which stock will be purchased to obtain a greater yield. 


\section{REFERENCES}

[1] Amaliawati, Lia, 2001, Penilaian Kesehatan Bank, Fokus Volume 3 No. 1 Annual Report Bank Jabar

[2] Bank Indonesia, 2010, Krisis Global dan Penyelamatan Sistem Perbankan Indonesia, Jakarta, Bank Indonesia.

[3] Bank Indonesia, 2004, Laporan Bank Indonsiatahun 2004, Jakarta

[4] Budisantoso, Totol and Triandaru, Sigit, 2006. Bank dan Lembaga Keuangan Lain, Salemba Empat, Jakarta

[5] Cooper, Donald R., and Schindler Pamela S., 2003 Business Research Methods, Tata Mc Graw- Hill.

[6] Dendawijaya, Lukman, 2009, Manajemen Perbankan, $2^{\text {nd }}$ edition, Ghalia Indonesia, Jakarta

[7] Dimitropoulos, Panagiotis, E. 2010, The Relevance of earnings and cash flows in a heavily regulated industry: Evidence from the Greek Banking sector, pages 290 - 303, Advances in Accounting

[8] Easton, P.D. and Harris, T.S., 1991, Earnings as an explanatory variable for returns', The Journal of Accounting Research, Vol. 29 pp $19-36$.

[9] Financial Accounting Standard Board (FASB), Concept Statement No. 2

[10] Gitman, Lawrence J. And Chad J. Zutter, 2012, Principles of Management Finance, $13^{\text {th }}$ edition, Global Edition, Pearson Education Limited.

[11] Hasibuan, Malayu, 2005, Dasar dasar Perbankan, Bumi Aksara, Jakarta

[12] Husnan, Suad and Pudjiastuti Enny, 2004, Dasar Dasar Manajemen Keuangan, UPP AMP YKPN, Yogyakarta.

[13] Ikatan Akuntan Indonesia, 2004, Pernyataan Standar Akuntansi Keuangan No. 31 Financial Accounting Standars, Salemba empat, Jakarta.

[14] International Accounting Standard Board (IASB), IASB Frame Work, p 12 - 14

[15] Kasmir, 2004, Manajemen Perbankan, Radja Grafindo Persada, Jakarta

[16] Kasmir, 2010, Analisis Laporan Keuangan, $3^{\text {rd }}$ edition, Jakarta, Rajawali Pers

[17] Kasmir, 2012, Analisis Laporan Keuangan, 6th edition, Raja Grafindo, Jakarta.

[18] Kuncoro, Mudrajad and Suhardjono, 2004, Manajemen Perbankan, BPFE, Yogyakarta

[19] Mahmoeddin, As. 2010, Melacakkredit Bermasalah, Pustaka Sinar Harapan, Jakarta

[20] Martono and Harjito, Agus P, 2002, Manajemen Keuangan, Ekonisia, Yogyakarta.

[21] Peraturan Bank Indonesia No. 6/10/PBI/2004, Tanggal 12 April 2004 Tentang Sistem Penilaian Tingkat Kesehatan Bank, Jakarta

[22] Rahmadana, M. Fitri and Lumbanraja, Hafniah, 2002,
Analisis Pemakaian Kasa Kredit Pada Perum Pegadaian Kantor Wilayah Medan, Jurnal Ilmiah Manajemen dan Bisnis, Volume 02 No. 01 April 2002.

http://www.azuarjuliandi.com/openarticles/jurnalmanajemen and bisnis.html.

[23] Sekaran, Uma 2013, Research Methodology, for Business: A skill - Building Approach, $6^{\text {th }}$ edition, John Wiley and Son Inc, USA

[24] Simorangkir, O.P, 2004, Pengatar Lembaga Keuangan Bank dan Non Bank, Ghalia Indonesia, Jakarta.

[25] Tracy, A. John, 2008, Accounting for Dummies, $4^{\text {th }}$ edition, Willey Publishing

[26] Weygandt, Jerry J. Keiso, Donald E., and Kimmel, Paul D., 2012, Financial Accounting, $8^{\text {th }}$ edition, John Wiley and Son Inc, USA.

[27] Wirnkar, A.D and Tanko, M., 2008, Camels and Bank performance evaluation the way forward working paper, SSRN.

[28] William, Roger and Boundewign et.al, 2006, The European Foundation for Quality Management 2005, risk management the acceptance and management of risk is inherent to the business of banking and banks.

[29] Yudistira, D., 2004, Efficiency in Islamic Banking; An Empirical Analysis of Eighteen banks. Islamic Economic Studies 1291): 1 - 19

[30] Sircular Letter Bank Indonesia (BI) No. 26/5/BPPP, Tanggal 29 Mei 1993 Tentang Tata Cara Penilaian Kesehatan Bank. Jakarta

[31] Sircular letter Bank Indonesia (BI) No. 2/12/DPNP, Tanggal 12 Juni 2000, Tentang Penilaian Aktiva produktif dalam Penghitungan ATMR. Jakarta

[32] Sircular letter Bank Indonesia (BI) No. 3/30/DPNP, Tanggal 14 Desember 2001 Tentang Perhitungan Ratio Keuangan, Jakarta

[33] Sircular letter Bank Indonesia (BI) No. 3/31/DPNP, Tanggal 14 Desember 2001 Tentang Perhitungan Ratio Keuangan, Jakarta

[34] Sircular letter Bank Indonesia (BI) No. 3/33/DPNP, Tanggal 14 Desember 2001, Tentang Ketentuan Umum Bank Umum, Jakarta

[35] Sircular letter Bank Indonesia (BI) No. 6/23/DPNP. Tanggal 31 Mei 2004, Tentang Tata Cara Penilaian Kesehatan Bank, Jakarta

[36] Regulation Bank Indonesia (BI) No. 23/67/Kep/DIR, Tanggal 28 Februari 1991, yang di pertegas melalui PBI No. 3121/BBI/2001 Tentang Kewajiban Modal Minimum Bank, Jakarta

[37] Regulation Bank Indonesia No. 6/10/PBI/2004, Tanggal 12 April 2004 Tentang Sistem Penilaian Tingkat Kesehatan Bank, Jakarta

[38] http://www.metrotvnews.com , April 2009

[39] http://www.idx.go.id, Indonesia Stock Exchange

[40] http://www.bi.go.id, Bank Indonesia 